\title{
PENGEMBANGAN LKS MATEMATIKA SAINTIFIK SMP KELAS VIII BERBASIS MULTIPLE INTELLIGENCES GARDNER
}

\author{
Enggar Prasetyawan ${ }^{1}$, Heri Indra Gunawan ${ }^{2}$ \\ ${ }_{1,2}$ Universitas Pamulang, Tangerang Selatan \\ dosen01927@unpam.ac.id
}

\begin{abstract}
This study aims to produce scientific mathematics worksheets for class VIII SMP based on multiple intelligences on the material of three-dimensional geometry that are valid, practical and effective. The development was carried out because of the limited math worksheets based on class VIII multiple intelligences on the material of three-dimensional geometry. This research is an R\&D research using the ADDIE model. The instruments used were in the form of student worksheet assessment sheets, teacher and student response questionnaires and learning achievement test questions to measure the effectiveness of the worksheets. The subjects of the trial were class VIII students of SMP Darussalam Islamic Boarding School Pulungsari which consisted of 25 students. The results of this study indicate that 1) the worksheets meet the valid criteria with a score of 96 from the material expert with a good category and a score of 81 from the media expert with a good category. 2) LKS meets the criteria of practicality with a score of 49 from the teacher's assessment in the very good category and a score of 68 from the student's assessment in the very good category. 3) LKS meets the criteria for effectiveness in terms of learning achievement.
\end{abstract}

Keywords: Mathematics worksheets, multiple intelligences

\begin{abstract}
Abstrak
Penelitian ini bertujuan untuk menghasilkan LKS matematika saintifik SMP kelas VIII berbasis multiple intelligences pada materi bangun ruang sisi datar yang valid, praktis, dan efektif. Pengembangan LKS ini dilakukan karena masih terbatasnya LKS matematika berbasis multiple intelligences kelas VIII pada materi bangun ruang sisi datar. Penelitian ini merupakan penelitian R\&D dengan menggunakan model pengembangan ADDIE (Analysis, Design, Development, implementation, dan Evaluation). Instrumen yang digunakan berupa lembar penilaian LKS oleh ahli materi dan ahli media untuk mengukur kevalidan LKS, angket respon guru dan siswa untuk mengukur kepraktisan LKS, serta soal tes prestasi belajar untuk mengukur keefektifan LKS. Subjek uji coba adalah siswa kelas VIII SMP Darussalam Islamic Boarding School Pulungsari yang terdiri atas 25 siswa. Hasil penelitian ini menunjukkan bahwa 1) LKS memenuhi kriteria valid dengan skor 96 dari ahli materi dengan kategori baik dan skor 81 dari ahli media dengan kategori baik. 2) LKS memenuhi kriteria kepraktisan dengan skor 49 dari penilaian guru pada kategori sangat baik dan skor 68 dari penilaian siswa berada pada kategori sangat baik. 3) LKS memenuhi kriteria efektif ditinjau dari prestasi belajar.
\end{abstract}

Kata kunci: LKS matematika, multiple intelligences

\section{PENDAHULUAN}

Semua negara baik di negara maju, berkembang, maupun negara yang baru merdeka menganggap pendidikan merupakan hal yang sangat penting. Pendidikan selalu diutamakan karena menjadi salah satu dasar dalam mengembangkan sumber daya manusia. Pendidikan yang baik akan menghasilkan sumber daya manusia yang baik pula dan hal tersebut sangat berguna dalam pembangunan suatu negara.

Matematika merupakan salah satu ilmu dasar yang memiliki peranan penting dalam mengembangkan kemampuan berpikir manusia. Oleh karena itu matematika menjadi salah satu pelajaran yang wajib dipelajari di sekolah. NCTM menyatakan bahwa pembelajaran matematika di sekolah bertujuan untuk meningkatkan kemampuan siswa dalam hal memahami matematika, dalam menyelesaikan masalah matematika, kepercayaan diri siswa, sikap siswa, dan tindakan siswa terhadap 
matematika (NCTM, 2000). Dalam pembelajaran matematika memiliki hubungan dengan kemampuan dan keterampilan dalam menyelesaikan masalah matematika. Pembelajaran yang efektif salah satunya memberikan kesempatan kepada siswa untuk terlibat langsung dalam proses belajar dan menyelesaikan masalah sehingga memfasilitasi siswa untuk memahami materi. Terwujudnya pembelajaran matematika yang efektif dibutuhkan pemahaman mengenai pengetahuan siswa, kebutuhan untuk belajar siswa, tantangan, serta dukungan untuk belajar dengan baik (Laksmiwati \& Retnowati, 2019).

Inovasi dalam pembelajaran matematika terus dilakukan untuk memperbaiki dan meningkatkan kualitas pembelajaran matematika. Pembelajaran yang aktif dan menyenangkan menjadi salah satu cara agar matematika dapat dipelajari siswa secara maksimal. Diberlakukannya kurikulum 2013 diharapkan menjadi solusi dalam memfasilitasi siswa belajar di sekolah. Guru dituntut untuk kreatif dan inovatif dalam menyusun perangkat pembelajaran. Salah satu komponen penting dalam perangkat pembelajaran adalah Lembar Kerja Siswa (LKS). Lembar Kerja Siswa (LKS) atau student work sheet adalah bahan ajar yang dikemas sedemikian rupa, sehingga siswa dapat mempelajari materi tertentu. LKS harus dikembangkan untuk menfasilitasi belajar yang aktif, interaktif, inspiratif, menyenangkan, menantang, dan dapat memotivasi siswa. LKS juga memiliki empat fungsi yaitu sebagai bahan ajar yang bisa meminimalkan peran pendidik, namun lebih mengaktifkan siswa, sebagai bahan ajar yang mempermudah siswa untuk memahami materi yang diberikan, sebagai bahan ajar yang ringkas dan kaya tugas untuk berlatih, dan LKS juga berfungsi untuk memudahkan pelaksanaan pengajaran kepada siswa (Prastowo, 2016).

LKS dapat berperan sebagai panduan siswa untuk melakukan kegiatan penyelidikan atau pemecahan masalah. Tidak hanya memberikan manfaat bagi siswa, LKS juga memudahkan guru dalam melaksanakan kegiatan pembelajaran (Majid, 2013). LKS merupakan bentuk usaha guru untuk membimbing siswa secara terstruktur, di mana kegiatannya memberikan daya tarik pada siswa untuk mempelajari matematika. Dengan menggunakan LKS, siswa dibimbing untuk menemukan suatu konsep secara bertahap sehingga siswa diharapkan benar-benar dapat memahami konsep matematika dengan baik. Penggunaan LKS dalam pembelajaran dapat mendorong siswa untuk lebih aktif dalam mengolah sendiri bahan yang dipelajari atau bersama temannya dalam suatu bentuk diskusi kelompok. Sehingga LKS harus benar-benar bisa dimanfaatkan dalam pembelajaran untuk membantu siswa memahami materi matematika. LKS yang ideal tidak hanya berisi soal-soal akan tetapi berisi langkahlangkah kegiatan yang menuntun siswa dalam melakukan pemecahan masalah.

Sebagai salah satu komponen perangkat pembelajaran, LKS harus mampu mengakomodasi setiap potensi yang dimiliki siswa. Dalam mengembangkan potensinya siswa memiliki kecerdasan yang beragam. Kecerdasan merupakan kemampuan sesorang untuk menggunakan pengetahuan (Laksmiwati \& Retnowati, 2019). Salah satu potensi siswa adalah potensi kecerdasan majemuk atau multiple intelligences (Sunendar, 2017). Kecerdasan majemuk membedakan setiap orang dengan 
orang lain (Gohar \& Sadeghi, 2015). Kecerdasan majemuk atau multiple intelligences merupakan faktor internal dalam pembelajaran, yaitu faktor dalam diri siswa yang mampu memengaruhi proses belajar siswa (Kartika, 2016). Multiple intelligences adalah berbagai ketrampilan dan bakat yang dimiliki siswa untuk menyelesaikan permasalahan dalam pembelajaran (Yaumi, 2012). Menurut Gardner, penting untuk mengetahui dan mengembangkan kecerdasan yang beraneka ragam pada manusia termasuk semua kombinasi dari kecerdasan-kecerdasan tersebut (Gardner, 1993). Ada delapan tipe kecerdasan yang dikemukakan oleh Gardner yaitu verbal-linguistik, logis-matematis, visual-spasial, musikal, interpersonal, intrapersonal, kinestetik, serta naturalis dan kemudian berkembang pula eksistensial sebagai kecerdasan kesembilan (Gardner, 1993).

Pembelajaran yang didesain dengan mempertimbangkan kecerdasan majemuk siswa akan membuat siswa lebih aktif belajar. Akan tetapi hingga saat ini keberadaan LKS yang berorientasi pada kecerdasan majemuk siswa masih sangat terbatas. Berdasarkan hasil wawancara dengan guru matematika di SMP Darussalam Islamic Boarding School Pulungsari diperoleh informasi bahwa LKS yang digunakan saat ini yaitu LKS yang banyak beredar di toko buku yang isinya hanya berisi ringkasan materi dan soal-soal saja. Untuk LKS matematika berbasis multiple intelligences masih belum ada di sekolah tersebut. Hal ini mengakibatkan potensi-potensi siswa yang dapat mendukung prestasi belajarnya tidak bisa dikembangkan dengan maksimal.

Selain itu Penelitian pengembangan ini bertujuan untuk menghasilkan LKS matematika saintifik SMP kelas VIII berbasis multiple intelligences Gardner yang dapat digunakan dalam pembelajaran di kelas. Penelitian pengembangan ini harus dilakukan karena potensi kecerdasan yang dimiliki siswa, melalui kecerdasan yang mereka miliki harus diperhatikan untuk mendukung keberhasilan proses belajar. LKS matematika berbasis multiple intelligences dalam pembelajaran saintifik pada kurikulum 2013 diharapkan akan mampu meningkatkan prestasi belajar siswa. Lebih lanjut dengan adanya LKS ini, diharapkan dapat memberikan kontribusi positif bagi perkembangan pendidikan di Indonesia.

\section{METODE}

Penelitian ini termasuk dalam jenis research and development atau penelitian dan pengembangan. Pengembangan dalam penelitian ini adalah pengembangan LKS matematika SMP Kelas VIII berbasis multiple intelligences. Model pengembangan yang digunakan adalah model ADDIE. ADDIE memiliki lima tahapan yaitu analysis (analisis), design (merancang), development (mengembangkan), implementation (uji coba) dan evaluation (evaluasi) (Branch, 2010). Prosedur pengembangan LKS dapat dilihat pada gambar berikut. 


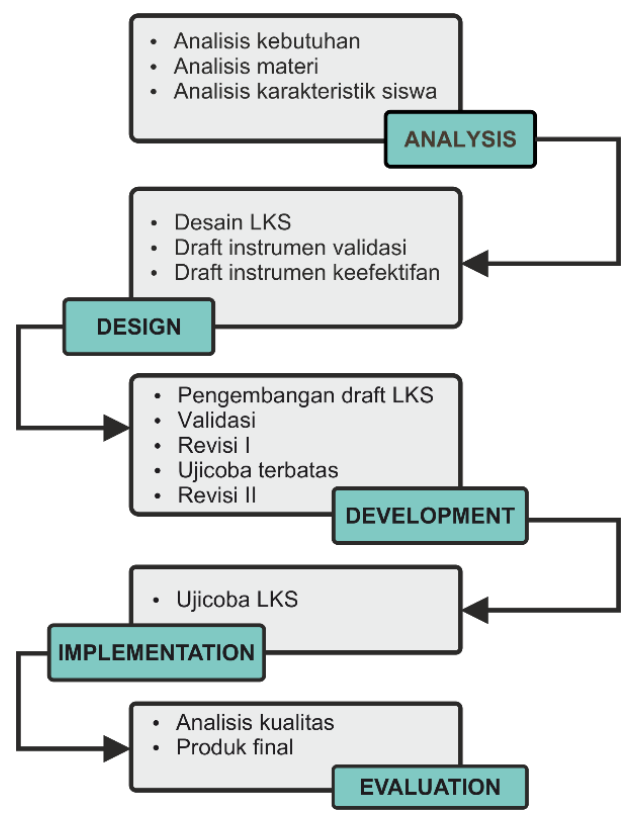

Gambar 1. Prosedur pengembangan LKS

Secara lengkap prosedur pengembangan pada penelitian ini adalah sebagai berikut:

\section{Tahap analisis(analysis)}

Pada tahap ini ketua dan anggota peneliti melakukan analisis kebutuhan akan pentingnya LKS berorientasi pada kecerdasan majemuk. Selanjutnya dilakukan analisis materi dan karakteristik siswa. Pada tahap ini juga dilakukan koordinasi dengan sekolah-sekolah yang akan digunakan sebagai lokasi penelitian.

\section{Tahap perancangan (design).}

Pada tahap ini ditentukan desain dari Lembar Kerja Siswa (LKS) matematika saintifik berbasis multiple intelligences dan pengembangan instrumen penelitian yang diperlukan. Pernacangan instrumen meliputi draft instrumen validasi dan draft instrumen untuk mengetahui efektifitas LKS.

\section{Tahap pengembangan (development)}

Pada tahap ini dilakukan pengembangan terhadap hasil yang telah disusun pada tahap design. Hasil dari tahap ini adalah draft I LKS Matematika kelas VIII berbasis multiple intelligences. Kemudian pada tahap ini dilakukan pula penilaian formatif oleh para ahli yang bertujuan untuk mengetahui apakah draft I LKS Matematika kelas VIII berbasis multiple intelligences yang telah dikembangkan valid atau tidak berdasarkan penilaian para ahli. Apabila hasil analisis penilaian para ahli terhadap draft I valid dan layak digunakan, maka dilanjutkan dengan uji coba draft I (terbatas). Namun apabila hasil analisis penilaian para ahli terhadap draft I tidak valid, maka diadakan revisi sehingga mendapatkan draft II.

\section{Tahap uji coba (implementation)}

Pada tahap ini LKS yang sudah di revisi diujicobakan kepada siswa di kelas. Uji coba yang dilakukan adalah uji coba lapangan pada sekolah yang dijadikan subjek penelitian untuk memperoleh kualitas 
produk. Target pada tahapan ini adalah diperoleh data mentah sebagai bahan analisis kualitas LKS dari segi keefektifan. Selain itu pada tahapan ini juga akan diperoleh masukan sebagai bahan revisi.

\section{Tahap evaluasi (evaluation).}

Evaluasi adalah proses untuk menganalisis keefektifan LKS matematika saintifik berbasis multiple intelligences yang dikembangkan serta revisi produk tahap II. Target akhir dalam tahapan ini adalah LKS matematika kelas VIII berbasis multiple intelligences final dan hasil analisa keefektifannya.

Subjek uji coba I (terbatas) pada penelitian pengembangan ini adalah dua belas siswa yang terdiri dari kelas VIII B, C, dan D yang berasal dari SMP Darussalam Islamic Boarding School Pulungsari. Sementara untuk subjek uji coba II melibatkan siswa kelas VIII A SMP Darussalam Islamic Boarding School Pulungsari yang terdiri atas dua puluh lima siswa.

Instrumen pengumpulan data yang digunakan yaitu instrumen untuk mengetahui kevalidan, kepraktisan, dan keefektifan. Jenis data yang diperoleh dari penelitian dan pengembangan ini adalah data kuantitatif dan kualitatif. Data kuantitatif diperoleh dari skor yang diberikan validator dalam tahap validasi, skor penilaian dari praktisi (guru) dan siswa. Data kualitatif diperoleh dari masukan validator dan juga dari konversi data kuantitatif ke kategori yang ditentukan. Data kuantitatif dengan skala lima dikonversikan menjadi data kualitatif, dengan acuan rumus yang diadaptasi dari (Widoyoko, 2012). Adapun acuan pengubahan skor disajikan dalam Tabel 1.

Instrumen pengumpulan data terdiri dari instrumen untuk mengetahui kevalidan terdiri atas lembar validasi LKS dan lembar validasi instrument tes prestasi belajar. Instrumen untuk mengetahui kepraktisan terdiri dari lembar penilaian guru dan lembar penilaian siswa. Instrumen untuk mengetahui keefektifan terdiri atas tes prestasi belajar.

LKS matematika yang dikembangkan di katakan valid jika hasil penilaian para ahli memperoleh kategori minimal baik. Bahan ajar matematika yang dikembangkan di katakan praktis jika hasil penilaian guru dan hasil penilaian siswa memperoleh kategori minimal baik. LKS matematika yang dikembangkan dikatakan efektif jika rata-rata nilai prestasi belajar siswa lebih dari 65 (KKM di SMP Darussalam Islamic Boarding School Pulungsari adalah 65).

Tabel 1.

Kriteria Konversi Data

\begin{tabular}{|c|c|}
\hline Rentang Skor & Kriteria \\
\hline$X \geq \overline{\mathrm{x}}+1,8 \mathrm{SB}_{\mathrm{x}}$ & Sangat Baik \\
\hline$\overline{\mathrm{x}}+0,6 \mathrm{SB}_{\mathrm{x}}<X \leq \overline{\mathrm{x}}+1,8 \mathrm{SB}_{\mathrm{x}}$ & Baik \\
\hline$\overline{\mathrm{x}}-0,6 \mathrm{SB}_{\mathrm{x}}<X \leq \overline{\mathrm{x}}+0,6 \mathrm{SB}_{\mathrm{x}}$ & Cukup Baik \\
\hline$\overline{\mathrm{x}}-1,8 \mathrm{SB}_{\mathrm{x}}<X \leq \overline{\mathrm{x}}-0,6 \mathrm{SB}_{\mathrm{x}}$ & Kurang Baik \\
\hline$X<\overline{\mathrm{x}}-1,8 \mathrm{SB}_{\mathrm{x}}$ & Tidak Baik \\
\hline
\end{tabular}

(Diadaptasi dari Widoyoko, 2012)

Keterangan:

X : skor responden 
Pengembangan LKS Matematika Saintifik SMP Kelas VIII Berbasis Multiple Intelligences Gardner, Enggar Prasetyawan, Heri Indra Gunawan

$\overline{\mathrm{X}} \quad$ : rata-rata ideal

$\mathrm{SB}_{\mathrm{X}} \quad$ : simpangan baku ideal

Dimana:

$\overline{\mathrm{x}} \quad=\frac{1}{2} \mathrm{x}$ (skor maks. ideal + skor min. ideal $)$

$\mathrm{SB}_{\mathrm{x}}=\frac{1}{6} \mathrm{x}($ skor maks. ideal - skor min. ideal)

Analisis untuk keefektifan LKS, menggunakan uji t dengan uji statistik yang digunakan menurut (Green \& Tatsuoka, 1973) sebagai berikut:

$$
t=\frac{\bar{x}-\mu_{0}}{\frac{S}{\sqrt{n}}}
$$

Keterangan:

$\bar{x} \quad$ : rata-rata

$\mu_{0} \quad$ : nilai yang dihipotesiskan

$S \quad$ : standar deviasi sampel

$n \quad$ : ukuran sampel

\section{HASIL}

Pengembangan LKS matematika kelas VIII berbasis multiple intelligences pada materi bangun ruang sisi datar telah dilakukan melalui tahapan ADDIE. Melalui tahapan tersebut, peneliti dapat mengetahui kualitas LKS yang dikembangkan. Adapun rincian hasil tahapan ADDIE sebagai berikut:

\section{Tahap analisis}

Berdasarkan wawancara dengan guru matematika diperoleh informasi bahwa LKS yang selama ini digunakan adalah LKS yang isinya hanya ringkasan materi dan soal-soal tanpa menuntun siswa untuk mendapatkan konsep materi pembelajarannya. Selain itu diperoleh informasi juga bahwa materi matematika siswa kelas VIII yang masih belum dapat dipahami dengan baik oleh siswa adalah materi bangun ruang sisi datar. Hasil identifikasi kecerdasan majemuk siswa yang dilakukan di kelas VIII D dapat dilihat dari hasil tes berikut.

Tabel 2.

Hasil Tes Identifikasi Kecerdasan Majemuk Siswa

\begin{tabular}{|c|c|c|}
\hline No. & Kecerdasan Majemuk & Rata-rata \\
\hline 1 & Verbal-linguistik & 29,13 \\
\hline 2 & Logis-matematika & 29,00 \\
\hline 3 & Visual-spasial & 21,16 \\
\hline 4 & Musikal & 22,59 \\
\hline 5 & Interpersonal & 28,63 \\
\hline 6 & Intrapersonal & 23,72 \\
\hline 7 & Kinestetik & 23,94 \\
\hline 8 & Naturalis & 21,53 \\
\hline 9 & Eksistensial & 22,06 \\
\hline
\end{tabular}


Dari data diketahui bahwa tiga kecerdasan dominan siswa yang diperoleh dari tes identifikasi kecerdasan adalah kecerdasan verbal-linguistik dengan rerata 29,13, kecerdasan interpersonal dengan rerata 28,63, dan kecerdasan logis-matematis dengan rerata 29,00.

\section{Tahap Design}

Dalam proses pengembangan media LKS ini, dilakukan pembuatan desain dan layout LKS berbasis multiple intelligences materi bangun ruang sisi datar menggunakan microsoft office word. Penyusunan LKS ini dilakukan dengan membuat kerangka terlebih dahulu dan berbasis pada tiga kecerdasan dominan yang terpilih sebagai dasar aktivitas pembelajaran dalam LKS. Integrasi tiga kecerdasan ini dapat diamati melalui simbol yang dapat dilihat pada gambar yang bertuliskan jenis kecerdasan.

Pada tahapan design LKS pertama merumuskan KD dengan menyesuaikan kurikulum 2013. Kedua, menentukan alat penilaian. Ketiga, menyusun materi dengan menyesuaikan KD dan materi dalam LKS berbasis multiple intelligence berupa informasi pendukung yaitu gambaran umum atau ruang lingkup substansi yang dipelajari dalam materi bangun ruang sisi datar seperti gambar-gambar dalam kehidupan sehari-hari. Keempat, memperhatikan struktur LKS yaitu judul, petunjuk belajar, tujuan pembelajaran, informasi pendukung, tugas, Langkah-langkah kerja, penilaian dan daftar Pustaka. Pada tahap ini juga disusun instrumen validasi LKS dan instrumen keefektifan LKS berupa soal tes prestasi belajar.

\section{Tahap Development}

Pada tahap pengembangan ini diperoleh hasil dari tahap perancangan yaitu berupa produk awal LKS matematika SMP kelas VIII berbasis multiple intelligence untuk materi bangun ruang sisi datar. LKS ini divalidasi oleh ahli materi dan ahli media yang melibatkan masing-masing satu validator. Pada validasi dihasilkan penilaian terhadap indikator-indikator LKS berbasis multiple intelligence untuk materi bangun ruang sisi datar. Hasil ini untuk mengetahui tingkat kelayakan LKS yang dikembangkan sebelum diberikan pada kelas uji coba. Setelah produk awal divalidasi, selanjutnya diadakan revisi berdasarkan saran dari validator. Adapun revisi dari validator dapat dilihat pada Tabel 3 berikut.

\section{Tabel 3.}

\section{Masukan Validator}

\begin{tabular}{|c|c|c|}
\hline Masukan Validator & Sebelum Revisi & Sesudah Revisi \\
\hline $\begin{array}{l}\text { Ditambahkan gambar } \\
\text { dadu dan diperbaiki } \\
\text { redaksional pada LKS } \\
1 \text { masalah 1 }\end{array}$ & 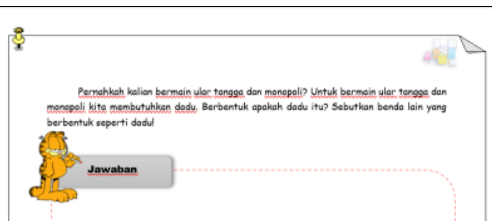 & $\underbrace{2}_{3}$ \\
\hline
\end{tabular}




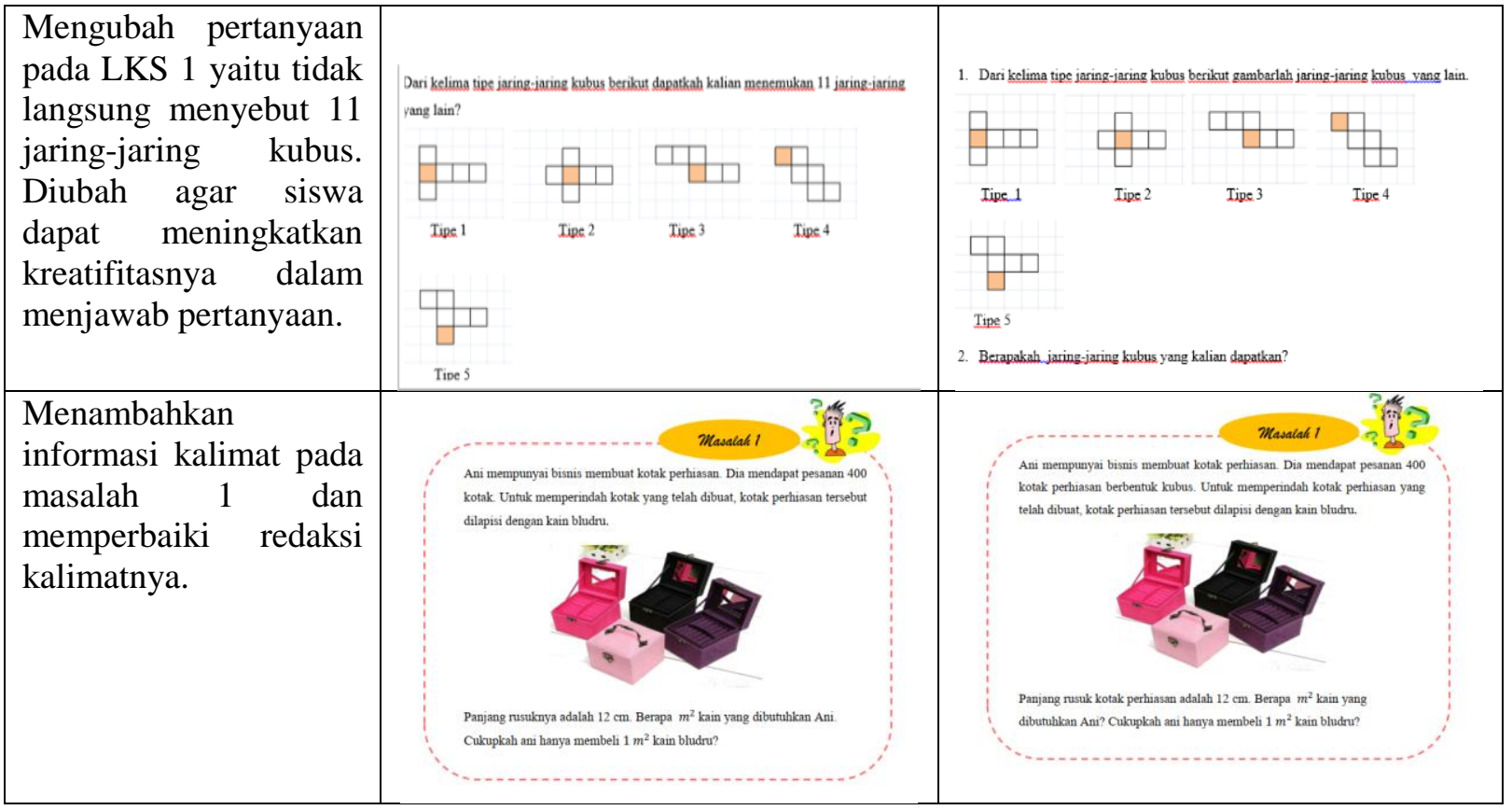

Hasil revisi LKS kemudian diujicobakan terbatas di SMP Darussalam Islamic Boarding School Pulungsari. Hasil penilaian validasi dapat dilihat pada Tabel 3. Ujicoba terbatas ini dilakukan di kelas VIII B, C, D sebanyak 12 siswa. Setelah dilakukan ujicoba terbatas produk LKS direvisi kembali untuk mendapatkan produk LKS matematika berbasis multiple intelligence yang siap diujicobakan pada kelas besar.

\section{Tahap Implementation}

Pada tahap ini dilakukan ujicoba pada subjek penelitian yang telah ditentukan yaitu siswa kelas VIII A di SMP Darussalam Islamic Boarding School Pulungsari sebanyak 25 siswa. Proses implementasi LKS yang dikembangkan berlangsung selama 8 pertemuan. Berdasarkan hasil penelitian tahap implementation diperoleh data meliputi data kepraktisan yang diperoleh dari respon siswa dan guru terhadap LKS yang dikembangkan dan data keefektifan yang diperoleh dari ketuntasan belajar siswa setelah pembelajaran menggunakan LKS.

\section{Tahap Evaluasi}

Hasil dari tahapan evaluasi adalah hasil analisis kepraktisan dan keefektifan LKS yang dikembangkan. Adapun data kepraktisan dan keefektifan dapat dilihat pada Tabel 4. Tampilan produk LKS matematika kelas VIII berbasis multiple intelligence pada materi bangun ruang sisi datar dapat dilihat pada gambar 2.

Produk pengembangan yang berkualitas memenuhi kriteria kevalidan, kepraktisan, dan keefektifan (Nieveen, 1999). Dengan demikian, berdasarkan hasil validasi ahli dan uji coba lapangan diketahui bahwa LKS matematika kelas VIII berbasis multiple intelligences pada materi bangun ruang sisi datar yang dikembangkan telah memenuhi kriteria valid, praktis, dan efektif ditinjau dari prestasi belajar. Secara umum data hasil analisis penelitian ini dapat dilihat pada tabel 4. 

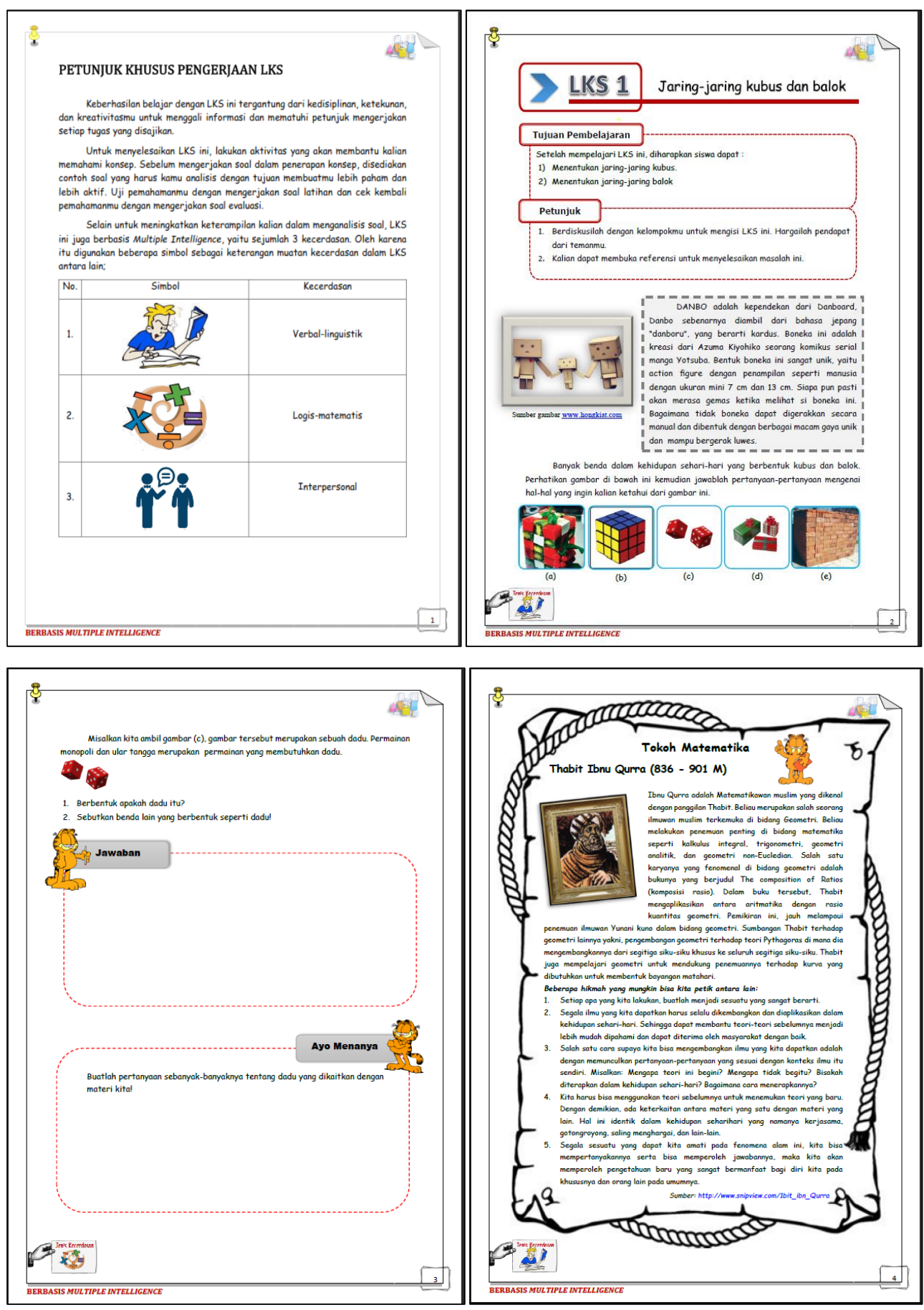

Gambar 2. Tampilan LKS Multiple Intelligences Final

Tabel 4.

Rekapan Hasil Analisis Penelitian

\begin{tabular}{|l|c|c|c|}
\hline \multicolumn{1}{|c|}{ Responden } & Kriteria & Nilai Empiris & Kategori \\
\hline Ahli Materi & Valid & 96 & Baik \\
\hline Ahli Media & Valid & 81 & Baik \\
\hline Guru & Praktis & 49 & Sangat Baik \\
\hline Siswa (kelas) & Praktis & 68 & Sangat Baik \\
\hline Siswa (kelas) & Efektif & 83 & Tuntas \\
\hline
\end{tabular}


Untuk kriteria kevalidan, berdasarkan penilaian yang dilakukan oleh ahli materi dan ahli media, produk akhir LKS matematika kelas VIII berbasis multiple intelligences pada bangun ruang sisi datar telah memenuhi kriteria valid. Untuk ahli materi telah memenuhi kriteria valid dengan kategori baik dengan skor empiris 96 dari rentang skor 24 sampai 120. Untuk ahli media telah memenuhi kriteria valid dengan kategori baik dengan skor empiris 81 dari rentang skor 20 sampai 100. LKS juga telah direvisi berdasarkan saran dan masukan dari ahli sehingga layak untuk digunakan. LKS yang dikembangkan telah dinyatakan valid karena dalam proses penyusunannya atau pengembangannya peneliti selalu berlandaskan pada teori-teori yang relevan.

Untuk kriteria kepraktisan, berdasarkan data uji coba lapangan menunjukkan hasil penilaian guru terhadap LKS matematika kelas VIII berbasis multiple intelligences pada materi bangun ruang sisi datar yang dikembangkan berada pada kategori sangat baik dengan skor empiris 49 dari rentang skor 12 sampai 60. Sedangkan hasil penilaian siswa terhadap LKS yang dikembangkan berada pada kategori sangat baik dengan skor empiris 68 dari rentang skor 16 sampai 80. Berdasarkan hasil uji coba lapangan tersebut dapat dikatakan bahwa LKS matematika kelas VIII berbasis multiple intelligences memenuhi kriteria kepraktisan.

LKS dikatakan memenuhi kriteria praktis dikarenakan peneliti dan guru mata pelajaran matematika sebagai pelaksana melakukan kegiatan refleksi pasca pembelajaran matematika berlangsung. Refleksi tersebut dilakukan untuk mengetahui kekurangan-kekurangan yang terjadi selama proses pembelajaran matematika dengan menggunakan LKS matematika berbasis multiple intelligences. Jika terjadi kekurangan pada pertemuan tersebut maka dilakukan upaya perbaikan untuk proses pembelajaran pada pertemuan selanjutnya. Guru diminta untuk lebih mengerti dan memaknai aktivitas-aktivitas pada LKS dan mengupayakan pengelolaan waktu secara efektif dan efisien. Selain itu guru diminta lebih memberikan pengarahan dan bimbingan pada siswa ketika ada kegiatan diskusi kelompok dan aktivitas-aktivitas lain sesuai dengan kegiatan di LKS.

Untuk kriteria keefektifan, diperoleh nilai rata-rata tes prestasi belajar matematika dengan menggunakan LKS matematika berbasis multiple intelligences sebesar 83 dari rentang skor 0 sampai 100. Nilai signifikansi dari data tes prestasi belajar matematika adalah $0,00<\alpha=0,05$, maka artinya pengembangan LKS matematika kelas VIII berbasis multiple intelligences pada materi bangun ruang sisi datar efektif ditinjau dari prestasi belajar siswa. Efektifnya LKS matematika kelas VIII berbasis multiple intelligences ini karena dalam pembelajaran mengupayakan keterlibatan siswa yang tinggi dalam setiap pembelajaran. Dalam pembelajaran terdapat kegiatan-kegiatan yang bervariasi yang dapat memberdayakan multiple intelligences siswa sehingga memberikan dampak positif pada prestasi belajar siswa.

\section{KESIMPULAN}

Pengembangan LKS matematika kelas VIII berbasis multiple intelligences ini menggunakan model ADDIE yang mencakup lima tahapan. Tahap pertama, analysis yaitu analisis kebutuhan 
diantaranya analisis materi dan karakteristik siswa. Tahap kedua, design berupa pengembangan desain LKS dan draft instrumen validasi, praktis, dan keefektifan. Tahap ketiga, development yaitu pengembangan draft LKS, melakukan validasi dari ahli, revisi I, uji coba terbatas, dan revisi II. Tahap keempat, implementation yaitu melakukan uji coba LKS di sekolah. Tahap kelima, evaluation yaitu analisis kualitas LKS dari segi keefektifan.

Kualitas produk hasil pengembangan penelitian ini ditentukan berdasarkan tiga aspek yaitu aspek kevalidan, kepraktisan, dan keefektifan. Berdasarkan hasil penelitian dan pembahasan dapat disimpulkan bahwa LKS matematika kelas VIII berbasis multiple intelligences pada materi bangun ruang sisi datar memenuhi kriteria valid dengan kategori baik berdasarkan penilaian ahli materi dan ahli media, kriteria praktis dengan kategori sangat baik berdasarkan penilaian guru dan siswa, dan memenuhi kriteria efektif ditinjau dari prestasi belajar.

Saran pemanfaatan produk yang dikembangkan adalah diharapkan guru matematika dapat menggunakan LKS ini untuk meningkatkan prestasi belajar siswa khususnya kelas VIII, siswa SMP kelas VIII dapat memanfaatkan LKS ini sebagai salah satu alternatif sumber belajar dalam meningkatkan prestasi belajarnya.

\section{DAFTAR PUSTAKA}

Branch, R. M. (2010). Instructional design: The ADDIE approach. In Instructional Design: The ADDIE Approach. https://doi.org/10.1007/978-0-387-09506-6

Gardner, H. (1993). Multiple intelligences: the theory in practice. In Choice Reviews Online (Vol. 31, Issue 02). https://doi.org/10.5860/choice.31-1214

Gohar, M. J., \& Sadeghi, N. (2015). Gardner's Multiple Intelligence Theory and foreign language achievement. International Journal of English and Education, 4(1), 206-216.

Green, B. F., \& Tatsuoka, M. M. (1973). Multivariate Analysis: Techniques for Educational and Psychological Research. Journal of the American Statistical Association, 68(341), 238. https://doi.org/10.2307/2284180

Kartika, A. (2016). Pengembangan Perangkat Pembelajaran Matematika SMA Kelas X pada Materi Trigonometri dan Geometri dengan Pendekatan Problem-Based Learning Berbasis Multiple Intelligences Gardner Berorientasi pada Prestasi, Kemampuan Koneksi Matematis, dan SelfEsteem Sisw [Universitas Negeri Yogyakarta]. https://eprints.uny.ac.id/41216/

Laksmiwati, P. A., \& Retnowati, E. (2019). Pengembangan perangkat pembelajaran geometri berbasis kecerdasan majemuk siswa SMP kelas VIII. Pythagoras: Jurnal Pendidikan Matematika, 14(1), 1-11. https://doi.org/10.21831/pg.v14i1.26591

Majid, A. (2013). Perencanaan Pembelajaran Mengembangkan Kompetensi Guru. In Bandung: PT Remaja Rosdakarya.

NCTM. (2000). Principles and Standards for School Mathematic. The National Council of Teachers of Mathematics, Inc.

Nieveen, N. (1999). Prototyping to Reach Product Quality. In Design Approaches and Tools in Education and Training. https://doi.org/10.1007/978-94-011-4255-7_10 
Pengembangan LKS Matematika Saintifik SMP Kelas VIII Berbasis Multiple Intelligences Gardner, Enggar Prasetyawan, Heri Indra Gunawan

Prastowo, A. (2016). Metode Penelitian Kualitatif dalam Perspektif Rancangan. Jurnal Fokus Konseling, 2(2), 144-159.

Sunendar, A. (2017). Perangkat Pembelajaran Matematika Berbasis Teori Kecerdasan Majemuk Apa dan Bagaimana Mengembangkannya. Jurnal THEOREMS: The Original Research of Mathematics, 1(2), 1-12.

Widoyoko, E. P. (2012). Teknik penyusunan instrumen penelitian. In Yogyakarta: Pustaka Pelajar.

Yaumi, M. (2012). Pembelajaran Berbasis Multiple Intelligences. Jakarta: Dian Rakyat. 